\title{
Foreign direct investment inflows to Malaysia: Do macroeconomic policies matter?
}

\author{
Atif Awad \\ College of Business Administration, Department of Finance \& \\ Economics, University of Sharjah, Sharjah, United Arab Emirates, \\ $U A E$ \\ aawoad@sharjah.ac.ae
}

Abstract. Malaysia plans to become a high-income economy in the coming years via what is called the ETP (Economic Transformation Program). To achieve this, Malaysia requires a sufficient level of foreign capital and thus is implementing appropriate investment initiatives to stimulate economic activity. So far, Malaysia has only been able to attract a small number of foreign investors. With a relatively small amount of FDI flowing into the country, the expectations of the Economic Transformation Program (ETP) that heavily rely on FDI may be challenged. The current paper analyses how selected macroeconomic factors might impact the flow of FDI into Malaysia. The ARDL (Auto-Regressive

$$
\begin{array}{r}
\text { Received: } \\
\text { August, 2019 } \\
\text { 1st Revision: } \\
\text { November, 2019 } \\
\text { Accepted: } \\
\text { February, 2020 } \\
\text { DOI: } \\
10.14254 / 2071- \\
8330.2020 / 13-1 / 13
\end{array}
$$
Distributed Lag) technique was used together with the VAR (Vector Autoregressive Model) on annual data (1970-2017). The study has found that over time, appreciation of the local currency, openness, inflation and labour cost had a significant negative impact on the inward flow of FDI. Conversely, over the longer term, real interest rate and GDP growth produced substantial positive effects on FDI. The findings suggest that when aiming to create an attractive for FDI environment, it is necessary for governments to closely consider macroeconomic policies that lower both production and transaction costs of multinational enterprises.

Keywords: foreign direct investment, openness, exchange rate, Malaysia.

JEL Classification: F21, F4, F41

\section{INTRODUCTION}

Malaysia plans to become a high-income economy in the coming years via the ETP (Economic Transformation Program), thereby increasing the per capita income from US $\$ 6,700$ to US $\$ 15,000$. To achieve this, Malaysia requires a sufficient level of capital and appropriate investment initiatives to stimulate economic activity. By 2020, the ETP is expected to create around 2.2 million jobs and to be generating RM 500b GNI annually. It is anticipated that $92 \%$ of the investment, including FDI, will flow 
from the private sector. In its quest to become a high-income economy by 2020, Malaysia will likely remain reliant on the growth of multinational enterprises (MNEs) and the associated FDI (foreign direct investment). Nevertheless, new information on the distribution of FDI worldwide shows that Malaysia has only been able to attract a small number of foreign investors (see Figure 1.). Compared to neighboring ASEAN countries, during the period 1970-2014, Malaysia received, on average, only $0.43 \%$ annually from the world's FDIs. During the same period, China, Singapore, Korea, Japan and Thailand received, on average, $6.6 \%, 2.41 \%, 0.67 \%$ and $0.62 \%$ of the world's FDIs respectively. With this relatively small amount of FDI flowing into Malaysia, the expectations of the ETP (Economic Transformation Program) that rely heavily on FDI may be challenged.

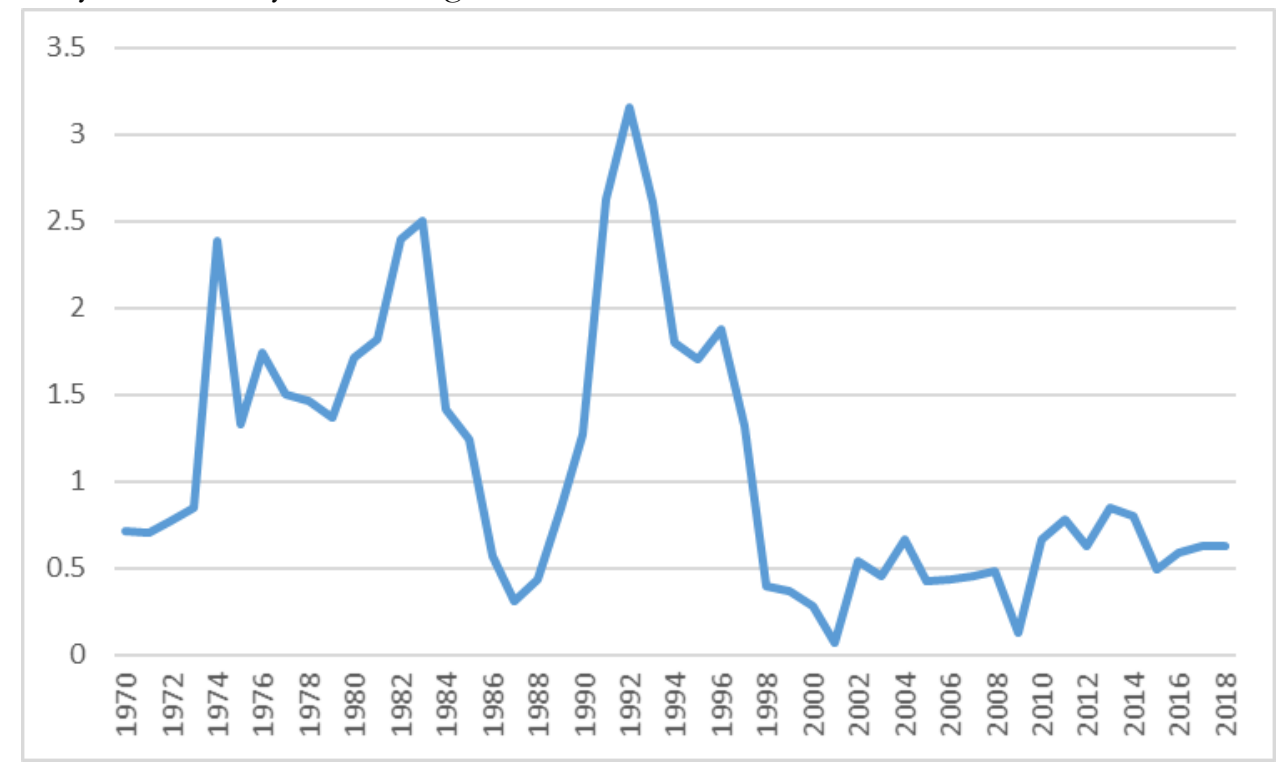

Figure 1. Inward FDI (\% of the world) in Malaysia, 1970-2018

The question is why do firms make the choice to create or gain foreign-based value-added activities as opposed to exporting directly to foreign firms? The FDI trends have been explained in prior literature, mainly focusing on industry and firm-specific variables. However, more recently, while developing upon earlier studies, there has been fresh interest expressed by researchers in the growth of MNEs at foreign markets and how spatial aspects of FDI influence this. The fact that many countries will compete to attract the inflows of FDI has spurred the interest in studying the location aspects of FDI, as suggested by Dunning (1998). Therefore, any modifications made by host countries to improve their attractiveness are vital for drawing additional FDI. In the 1970s, FDI location decisions were principally influenced by such factors as natural resource availability, physical infrastructure, allowing resources to be exploited, government restrictions and other investment incentives, according to (Dunning, 2009). Interestingly, in more recent years these factors have played a relatively less significant role. Dunning (2009) argued that macroorganizational and macroeconomic policies pursued by host governments have a more critical role, comparable to the location decision variables considered by MNE's in the 1990s. Other scholars have confirmed the importance of macroeconomic factors in explaining aggregate FDI trends over time (Vasconcellos \& Kish, 1998; Boateng, Nisar, \& Wu, 2015; Uddin et al., 2019; Polyxeni \& Theodore, 2019). Macroeconomic variables in host nations and their effects on the inbound flow of FDI have received little study from researchers to date, even though these factors are potentially essential. The lack of research on this issue could be because economists either have little interest in the subject, or they are already satisfied, in general, with the current explanations of the FDI inflows, according to Dunning (2009). Subsequently, 
Dunning (2009) opined: "does one need to reconsider the policy implications for national and regional governments as they seek to advance their particular economic and social objectives?” (pp. 12). Dunning reasonably answered this question, he recommended additional empirical studies on how macroeconomic factors influence FDI. In the present study, we have sought to determine the implications of the FDI inflows as a result of governmental policies. Specifically for Malaysia, we studied the effect on inward FDI of macroeconomic influences during 1970-2014. Therefore, the main question of this study is: how great is the extent of macroeconomic policies' effect on the inflow of FDI into Malaysia?

This paper is organised in the following way: Section one is the introduction, while Section two discusses the model and the theoretical background. The methodology and estimation procedures are presented in Section three. Section four details the empirical findings. Section five ends with conclusion and policy recommendations.

\section{MODEL AND THEORETICAL BACKGROUND}

Following preceding empirical studies that addressed the same issue such as Saini and Singhania (2018) and Xuan (2018), we estimated, using the following equations, to determine the impacts of Malaysia's macroeconomic variables on inward FDI:

$$
\begin{gathered}
F D I_{t}=\alpha_{0}+\alpha_{1} O P_{t}+\alpha_{2} I N F_{t}+\alpha_{3} E X_{t}+\alpha_{4} G D P_{t}+\alpha_{5} R A T_{t}+\alpha_{6} L P_{t}++\varepsilon_{t} \\
F D I_{t}=\alpha_{0}+\alpha_{1} O P_{t}+\alpha_{2} I N F_{t}+\alpha_{3} E X_{t}+\alpha_{4} G D P_{t}+\alpha_{5} R A T_{t}+\alpha_{6} L P_{t}++\varepsilon_{t} \\
F D I_{t}=\alpha_{0}+\alpha_{1} O P_{t}+\alpha_{2} I N F_{t}+\alpha_{3} E X_{t}+\alpha_{4} G D P_{t}+\alpha_{5} R A T_{t}+\alpha_{6} L P_{t}+\alpha_{7} E F I_{t}+\varepsilon_{t} \\
F D I_{t}=\alpha_{0}+\alpha_{1} O P_{t}+\alpha_{2} I N F_{t}+\alpha_{3} E X_{t}+\alpha_{4} G D P_{t}+\alpha_{5} R A T_{t}+\alpha_{6} O L P_{t}+\alpha_{7} E F I_{t}+\varepsilon_{t}
\end{gathered}
$$

FDI denotes inward foreign direct investment (\% world), OP represents the openness of an economy measured in terms of exports plus imports over total GDP (all variables in 2005\$). INF expresses the inflation rate (change in CPI), EX is the real effective exchange rate (calculated as the nominal effective exchange rate (the value of a currency against a weighted average of other foreign currencies) divided by a price deflator or index of costs). GDP denotes the real gross domestic product, and RAT expresses the real interest rate (calculated as the lending interest rate adjusted for inflation as measured by the GDP deflator). LP represents the labour force (the number) and $\varepsilon_{t} \varepsilon_{t}$ is the error term. Except for data regarding FDI which was obtained from UNCTA, the other data were obtained from the World Bank Development Indicators (WBDI) database.

Table 1

Descriptive statistic

\begin{tabular}{|l|c|c|c|c|c|c|c|}
\hline & FDI & EX & GDP & INF & LP & OP & RAT \\
\hline Mean & 1.111045 & 134.1543 & 6.293144 & 3.597057 & 7.652288 & 146.0641 & 4.189225 \\
\hline Median & 0.833083 & 121.5285 & 6.652035 & 3.142991 & 7.319000 & 154.0829 & 4.451532 \\
\hline Maximum & 3.068840 & 215.4427 & 11.71420 & 17.32898 & 13.63460 & 220.4074 & 11.78251 \\
\hline Minimum & 0.066123 & 91.87243 & -7.359416 & 0.290008 & 2.546601 & 69.25857 & -3.903776 \\
\hline Std. Dev. & 0.773803 & 38.60282 & 3.684240 & 2.969593 & 3.107617 & 48.01431 & 3.429586 \\
\hline Observations & 45 & 45 & 45 & 45 & 45 & 45 & 45 \\
\hline
\end{tabular}

Source: Own calculation 
Correlation

\begin{tabular}{|c|c|c|c|c|c|c|c|}
\hline & FDI & EX & GDP & INF & LP & OP & RAT \\
\hline FDI & 1.000000 & 0.371807 & 0.425918 & 0.468153 & -0.424287 & -0.348281 & 0.038173 \\
\hline EX & 0.371807 & 1.000000 & 0.209731 & 0.370727 & -0.906837 & -0.920611 & 0.329050 \\
\hline GDP & 0.425918 & 0.209731 & 1.000000 & 0.235506 & -0.268629 & -0.198036 & 0.001460 \\
\hline INF & 0.468153 & 0.370727 & 0.235506 & 1.000000 & -0.390897 & -0.316850 & -0.005410 \\
\hline LP & -0.424287 & -0.906837 & -0.268629 & -0.390897 & 1.000000 & 0.830289 & -0.336483 \\
\hline OP & -0.348281 & -0.920611 & -0.198036 & -0.316850 & 0.830289 & 1.000000 & -0.271701 \\
\hline RAT & 0.038173 & 0.329050 & 0.001460 & -0.005410 & -0.336483 & -0.271701 & 1.000000 \\
\hline
\end{tabular}

Source: Own calculation

It is possible to classify, into three key categories, the empirical and theoretical research on international trade that has concentrated on the motivations for FDI by multinational enterprises (MNEs). The categories suggested are; the vertical motivations (Helpman, 1984; Helpman \& Krugman, 1985); the horizontal motivations (Markusen, 1984; Markusen \& Venables, 1998), and the knowledge-capital model (Carr, Markusen, \& Maskus, 2001), which combined the horizontal and vertical models. In brief, the relationship between trade cost and FDI is as follows; for the horizontally motivated FDI, an increase in the trade cost (i.e. tariffs) within the hosting country will increase the flow of FDI into the country, and vice-versa. Therefore, FDI and trade should be considered as alternatives for each other in the horizontally motivated FDI model.

In contrast, vertically motivated FDI will reduce as the costs of trade increase and the gap in the labour cost between the home and the host country increases (Levy -Yeyati, Ernesto, \& Christian, 2003; Lesher \& Miroudot, 2006; Wadhwa \& Reddy, 2011; Busse \& Hefeker, 2007). Therefore, in the vertically motivated FDI model, FDI and trade tend to be complementary. Both the horizontally and vertically motivated FDI motives are incorporated into the knowledge-capital model to analyze the influence of several factors on FDI. Using the knowledge-capital model, it was shown that the cost of trade had a positive effect on FDI when the difference in the labour cost between the home and the host countries was small but it had a negative impact when the labour cost difference was substantial, according to Carr et al. (2001). It seems that when the cost of trade falls, a decrease in the horizontally motivated FDI will dominate over an increase in the vertically motivated FDI when there is a small difference in the labour cost between the home and the host countries; and vice versa, in the event that the difference in labour cost is large (Jang, 2011).

It was noted by Billington (1999), that a greater level of availability of labour in a host country would make the country more attractive to foreign investors. According to Dunning (1980) and UNCTAD (1994), an increase in the size of the labour force implies labour input abundance; and hence a lower cost of labour. They also suggested the use of the labour force and not wages as a proxy for labour cost. This is because wages may reflect the skill level of the labour force, and hence be reflected in higher wages (or higher costs); which implies the existence of high-skill workers in the country. In this case, and in spite of the increasing cost of labour (which is against the efficiency of production), FDI might continue to flow into a country to take advantage of the high-skill workers (UNCTAD 1999; Noorbakhsh, Palani, \& Youssef, 2001). In the present study, we used the total size of the labour force as a proxy for the labour cost.

Although several empirical inquiries have confirmed the existence of a strong relationship between FDI and the level of the exchange rate, there is still ambiguity in the form of this relationship. Due to FDI being heterogeneous and complicated by its nature; several theoretical models have been used to explain 
the movement of FDI (Phillips \& Ahmadi-Esfahani, 2008; Egger \& Merlo, 2007). The existing theoretical models have found the sign between the predicted relationship of the exchange rate and FDI to be variable and a number of the current models have predicted an ambiguous result. In essence, this is due to both the FDI and the exchange rate being dependent on factors such as the arrangement of revenues and costs, the type of FDI, or the source of exchange rate shock. For instance, several mechanisms are possible, in the case of horizontally motivated FDI. A depreciation of the host country's exchange rate will ensure a positive effect on the inbound flow of horizontally motivated FDI as a result of the reduced cost of capital, as predicted by Aliber (1993). If the local currency appreciates this will also increase the flow of horizontally motivated FDI as consumers locally will experience greater purchasing power. An appreciation of a local currency would cause a negative effect on vertically motivated inbound FDI as locally produced items would become more expensive when exported. Due to the existence of many factors that can affect the association between FDI and the exchange rate, empirical work must be undertaken to examine what, if any, is the form that the relationship may take (Faeth, 2009).

The level of the inflation rate confers economic stability, the presence of internal economic tension and the ability of the government to balance the national budget. A high level of inflation reduces, in the local currency, the real value of earnings for firms that are inwardly investing (Boateng et al.,2015; Xaypanya, Rangkakulnuwat, \& Paweenawat, 2015; Buckley et al., 2007; Faeth, 2009). Conversely, a low level of inflation indicates internal national economic stability and urges inbound FDI, (Xaypanya et al., 2015). The FDI inflows into Turkey were studied, by Coskun (2001), and revealed that a lower level of inflation was inclined to attract foreign investors and grow inbound FDI. The main factors influencing the flow of FDI into ASEAN+3 (Cambodia, Laos, and Vietnam) was investigated by Xaypanya et al. (2015), the study discovered a statistically negative impact for the inflation rate.

The interest rate was verified as one of the significant determining factors of the location choice for inbound FDI in seven industrialized nations, Billington (1999). Comparable results were confirmed by Hong and Kim (2002), they determined that the lower rates of interest in some European Union countries were a key factor when deciding upon favored locations for the manufacturing sites for Korean MNEs in the EU region. Culem (1988), showed evidence to support the prominence of the low rates of interest of host countries when attracting inbound FDI, he stated that low rates of interest offered investors a cost advantage. Conversely, it was proposed by Yang, Groenewold and Tcha (2000) and Jeon and Rhee (2008), that a high rate of interest in the host country would result in FDI being more attractive as it would offer more profitable investments. The above argument suggests that high or low-interest rates can stimulate FDI. However, some studies have detected an insignificant relationship between inward FDI and the interest rate (Faeth, 2009; Boateng, Naraidoo, \& Uddin, 2011).

It was found by Fedderke and Romm (2006) and Moosa and Cardak (2006) that the size of a country's market when evaluated by the real GDP positively influenced the country's inbound FDI. This result was in parallel with Dunning's (1993) eclectic paradigm, which asserted that one of the primary motives for firms to invest abroad was to obtain improved access to the market of the host country and that of neighboring countries. Boateng et al., (2011), determined that larger market size in a host country, concerning the country's GDP, will attract a greater flow of FDI into the country. This can be explained by considering that as the country's market size is mirrored by the potential of greater demand in the economy and as a consequence there is greater acquisitive FDI, to meet the changed circumstances of the economy. To examine the impact of the FDI-market seeking hypothesis, we used the traditional proxy for the market size which is the real GDP annual growth rate (Faeth, 2009; Hossain \& Mitra, 2013, Cavallari \& Addona, 2013, Lautier \& Moreaub, 2012). 


\section{METHOD AND THE ESTIMATION PROCEDURES}

The ARDL test for co-integration, as proposed by Pesaran and Pesaran (1997), was employed in this study. This test conveys several econometric advantages, such as 1) It is possible to avoid the inability to test the hypotheses on the estimated coefficients in the long-run which is associated with the EngleGranger method and the problem of endogeneity. 2) The short-run and long-run parameters of the model are determined simultaneously. 3) It is assumed that all of the variables are endogenous. 4) The econometric methodology relieves the requirement to pre-test for unit roots; this applies whenever the underlying variables are $\mathrm{I}(0), \mathrm{I}(1)$, or fractionally integrated. 5), Using the ARDL method, different variables can have different lag lengths or a maximum number of lags selected which avoids the collinearity problem between the variables. Finally, the ARDL procedure rather than estimating the longrun relationship within a context of system equations, as in conventional cointegration procedures, only employs a single reduced from equation (Ozturk \& Acaravci, 2011).

Testing for the presence of a long-run association between the variables by conducting an F-test for the joint significance of the coefficients of the lagged levels of the variables is the first step in the ARDL method. As recommended by Pesaran and Pesaran (1997) and Pesaran, Shin and Smith (2001), as summarised in Choong, Yusop and Soo (2005), the augmented ARDL (p, q1, q2, q3,...qk) model can be displayed as follows:

$$
\varphi(L, P) y_{t}=C_{0}+\sum_{i=l}^{k} \varphi_{i}\left(l, q_{i}\right) x_{i t}+\gamma_{t} w_{t}+\varepsilon_{t}, t=1,2,3 \ldots \ldots \ldots \ldots \ldots \ldots
$$

where the dependent variable is denoted by $y, \mathrm{C} 0$ signifies the $(\mathrm{K}+1)$-vector of intercept, $\mathrm{x}$ represents the independent variable, $\mathrm{L}$ is the lag operator, and wt expresses the $(\mathrm{K}+1)$ vector of deterministic variables including dummy variables, intercept terms, time trends and other exogenous variables with fixed lags. The (conditional) unrestricted ECM version of the selected ARDL model can be obtained by rewriting Equation (2) in terms of the lagged levels and the first difference of $\mathrm{yt}, \mathrm{x} 1 \mathrm{t}, \mathrm{x} 2 \mathrm{t}, \ldots \ldots \mathrm{xkn}$ and wt as follows:

$$
\Delta y_{t}=C_{0}+C_{1} t+\theta_{x y} z_{t-1}+\sum_{i=1}^{p-1} \varnothing_{i} \Delta y_{t-1}+\sum_{i=0}^{p-1} \vartheta_{i} \Delta x_{t-1}+\lambda_{t} w_{t}+\grave{o}_{t}
$$

Where the first difference operator is $\Delta$, t represents the trend, the coefficient $\vartheta$ expresses the shortrun dynamics of the model's convergence to equilibrium and $z t=(y t, x t)$. Similarly, founded on Equation 1 the conditional VECM of interest can be expressed as follows:

$$
\begin{aligned}
\Delta F D I_{t}=C_{0}+ & \gamma_{1} F D I_{t-1}+\gamma_{2} O P_{t-1}+\gamma_{3} I N F_{t-1}+\gamma_{4} E X_{t-1}+\gamma_{5} G D P_{t-1}+\gamma_{6} O R A T_{t-1} \\
& +\gamma_{7} L P_{t-1}+\sum_{j=1}^{q} \varphi_{j} \Delta F D I_{t-j}+\sum_{n=1}^{q} \delta_{n} \Delta O P_{t-n}+\sum_{s=1}^{q} \emptyset_{s} \Delta I N F_{t-s} \\
& +\sum_{w=1}^{q} \xi_{w} \Delta E X_{t-w}+\sum_{g=1}^{q} \psi_{g} G D P_{t-g}+\sum_{h=1}^{q} v_{h} \Delta \operatorname{RAT}_{t-h}+\sum_{s=1}^{q} v_{h} \Delta \mathrm{LP}_{t-s}+\epsilon_{t}
\end{aligned}
$$

Where all of the variables are as defined previously, the first difference operator is $\Delta$, q represents the optimal lag length, the residuals $\omega_{i t}$ are assumed to be normally distributed and white noise. The null hypothesis of no cointegration in Equation 7 is that $\delta \mathrm{i}=0$. The F-test has a non-standard distribution, which depends on (i) if the variables that are included in the model are I(0) or I(1), (ii) the number of repressors, and (iii) if the model contains an intercept and/or a trend. Given the relatively small sample size in this study, just 51 observations, the critical values used, were as stated by Pesaran and Pesaran 
(1997). The test involved asymptotic critical value bounds, depending on whether the variables were $\mathrm{I}(0)$ or I(1), or a mixture of both. Two sets of critical values were generated in which one set referred to the $\mathrm{I}(1)$ series; and the other to the $\mathrm{I}(0)$ series.

If the statistics from the F-test exceeded their respective upper critical values, it was concluded that there was the presence of a long-run association among the variables regardless of the order of integration between the variables. If the test statistic fell below the lower critical value, it was not possible to reject the null hypothesis of no cointegration. If the test statistic lay between the bounds, it was not possible to make a conclusive interpretation without knowing the order of integration of the underlying repressors. Should the F-statistic fall between the lower bound and the upper bound critical value, it was recommended to consider using the t-test corresponding to ECT-1; if this was significant, it suggested the existence of cointegration among the variables (see Banerjee, Dolado, and Mestre, 1998; Mosayeb and Mohammad, 2009). The second step was only required if a long-run association was found in the initial step (Marashdeh, 2005). According to Pesaran and Pesaran, (1997), the presence of a cointegrated association implied that the selected explanatory variables were the long-run forcing variables for the dependent variables. In the first model, the presence of this association in Equation 4 shows the need to estimate the following long-run association:

$$
\begin{aligned}
F D I_{t}=C_{0}+ & \sum_{i=1}^{p} \lambda_{1} F D I_{t-i}+\sum_{i=0}^{q 1} \lambda_{2} O P_{t-i}+\sum_{i=0}^{q 2} \lambda_{3} I N F_{t-i}+\sum_{i=0}^{q 3} \lambda_{4} E X_{t-i}+\sum_{i=0}^{q 4} \lambda_{5} G D P_{t-i} \\
& +\sum_{i=0}^{q 5} \lambda_{6} R A T_{t-1}+\sum_{i=0}^{q 6} \lambda_{7} L P_{t-1}+\epsilon_{t}
\end{aligned}
$$

Where all of the variables are as previously defined. This comprises selecting the order of the ARDL (p, q1, q2, q3, q4, q5, q6) model in the six variables using the AIC (Akaike Information Criteria). As part of the third and final step, we found the short-run dynamic parameters by estimating an error correction model (ECM) associated with the long-run estimates for each equation. The ECM specification is expressed as follows:

$$
\begin{aligned}
\Delta F D I_{t}=\mu+ & \sum_{j=1}^{p} \varphi_{j} \Delta F D I_{t-j}+\sum_{n=1}^{q} \delta_{n} \Delta O P_{t-n}+\sum_{s=1}^{q} \emptyset_{s} I N F_{t-s}+\sum_{w=1}^{q} \xi_{w} \Delta E X_{t-w} \\
& +\sum_{g=1}^{q} \psi_{g} \Delta G D P_{t-g}+\sum_{h=1}^{q} v_{h} \Delta R A T_{t-h}+\sum_{s=1}^{q} v_{h} \Delta L P_{t-s}+\Omega e c m_{t-1}+\epsilon_{t}
\end{aligned}
$$

Here ${ }^{\varphi}, \delta, \phi, \xi, \psi \vee$ express the short-run dynamic coefficients of the model's convergence to equilibrium and $\Omega$ denotes the speed of adjustment. The significance of the ecmt-1 suggests a causality relationship in at least one direction. To ascertain the goodness of fit of the ARDL model, relevant diagnostic tests and stability tests were conducted.

\section{EMPIRICAL RESULTS}

\subsection{Unit root test}

We first examined the order of the cointegration for each of the variables, to ensure that no variable was I(2). Since the plotted figure of FDI showed that it did not exhibit a trend, the unit root tests were performed at the level and the first difference considering intercept only. The data series were tested for stationarity (i.e. the order of integration) using the Augmented Dickey-Fuller test (ADF, 1981) and the Kwiatkowski-Phillips-Schmidt-Shin test (KPSS, 1992). Table 3 presents the results of these tests at the 
level and the first difference. The results of both unit root tests confirmed each other and the findings of the unit root tests suggested that all the variables were integrated in mixed order $(\mathrm{I}(1)$ and $\mathrm{I}(0))$ each test confirmed the other test's results. Thus, the findings from the unit root tests confirmed the necessity to test for cointegration among these variables. The second step was to test whether there was a long-run association between the variables.

Table 3

Unit root tests

\begin{tabular}{|l|c|c|c|c|}
\hline \multirow{2}{*}{ The Variables } & \multicolumn{2}{|c|}{ At level } & \multicolumn{2}{c|}{ At first difference } \\
\cline { 2 - 5 } FDI & ADF & KPSS & ADF & KPSS \\
\hline OP & $\begin{array}{c}-2.35 \\
{[0.16]}\end{array}$ & $0.35^{*}$ & $\begin{array}{c}-6.26^{* * *} \\
{[0.000]}\end{array}$ & 0.07 \\
\hline INF & $\begin{array}{c}-0.87 \\
{[0.78]}\end{array}$ & $0.72^{* * *}$ & $\begin{array}{c}-3.97^{* * *} \\
{[0.003]}\end{array}$ & 0.08 \\
\hline EX & $\begin{array}{c}-2.92 \\
{[0.0523]}\end{array}$ & $0.48^{* *}$ & $\begin{array}{c}-5.77^{* * *} \\
{[0.000}\end{array}$ & 0.24 \\
\hline RAT & $\begin{array}{c}-1.94 \\
{[0.32]}\end{array}$ & $0.80^{* * *}$ & $\begin{array}{c}-4.42 \\
{[0.000]}\end{array}$ & 0.26 \\
\hline GDP & $\begin{array}{c}-5.35^{* * *} \\
{[0.001]}\end{array}$ & 0.26 & & \\
\hline LP & $\begin{array}{c}-5.47^{* * *} \\
{[0.000]}\end{array}$ & 0.31 & & 0.04 \\
\hline
\end{tabular}

Notes:

${ }^{1}$ In KPSS tests, the null hypothesis is that the variable is stationary, which is exactly opposite in the ADF test.

${ }^{2}$ The Asymptotic critical values for the Kwiatkowski-Phillips-Schmidt-Shin test statistic are equal to $0.73,0.46$ and 0.35 at $1 \%, 5 \%$ and $10 \%$ significance level, respectively.

${ }^{3}$ The critical value for, $\mathrm{t}$-statistic for $\mathrm{ADF}$ are $-3.58,-2.93$ and -2.60 at $1 \%, 5 \%$ and $10 \%$ significance level, respectively.

${ }^{4}(*),(* *),(* * *)$ in $(\mathrm{ADF})$ denote rejection of the null of non-stationary of the variable at $10 \%, 5 \%$ and $1 \%$ significance level, respectively.

$5(*),(* *),(* * *)$ in (KPSS) denote rejection of the null of the stationary of the variable at $10 \%, 5 \%$ and $1 \%$ significance level, respectively.

\subsection{Cointegration test}

The second step was to carry out the bounds test on Equation 4 and compute the F-statistic for the joint significance of the coefficients of the lagged levels of the variables. The results of the F-statistic test are presented in Table 3. It should be recalled that the optimal order of lags was selected for the models based upon the Schwarz-Bayesian information criteria (SBI), this was recommended by Pesaran et al. (2001). The AIC (Akaike Information Criteria) endorsed the optimal lags selected by the SBC (the results of the AIC are not included here but are available upon request). Thus, based upon the conclusion made on the results of the F-statistic test in Table 4, it was clear that a long-run association existed between the variables. Specifically, the F-statistic analysis detected a long-run relationship at a maximum lag length of 4. Therefore, from the table above it can be concluded that the variables OP, EX, RAT, LP, INF and GDP are long-run forcing variables that influenced the flow of FDI into Malaysia over the period 19702014. 
Table 4

F statistic test- Bound Test

\begin{tabular}{|c|c|c|c|c|c|}
\hline \multirow{2}{*}{ Specification } & \multicolumn{4}{|c|}{ Maximum Lag length } & \multirow{2}{*}{ Conclusion } \\
\hline & 1 & 2 & 3 & 4 & \\
\hline $\begin{array}{l}\text { FDI/(OP,INF. EX, } \\
\text { RAT,GDP,LP) }\end{array}$ & 2.45 & 2.99 & 3.16 & $5.69 *$ & $\begin{array}{c}\text { Cointegration at lag } \\
4\end{array}$ \\
\hline
\end{tabular}

Notes:

${ }^{1}$ First letter outside the brackets indicates to the dependent variables.

${ }^{2}$ The lower - upper critical value for the F test ( with intercept and no trend ) with six variables $(\mathrm{k}=6)$ are (3.27-4.54) and (2.82-4.07) at 99.5\%, and 99\% confidence level respectively.

${ }^{3}$ The critical value obtained from Pesaran \& Pesaran (1997).

$4\left(^{*}\right)$ denote significant at $99 \%$ level.

\subsection{Long and Short-Run Analysis}

Before the interpretation and discussion of the results, we performed relevant stability and diagnostic tests to ascertain the goodness of fit of the ARDL model. Based on Pesaran and Pesaran (1997), the diagnostic tests examined the stability of the long-run coefficients together with the short-run dynamics, we followed Brown, Durbin and Evans (1975), and their application of CUSUM and CUSUMSQ. Additional diagnostic tests were performed on the model, these include; a serial correlation test (F statistics of Breusch-Godfrey test); a model specification test (F statistics of ARCH); a normality test (Jarque-Bera test); and a Heteroskedasticity test ( $F$ statistics of white Heteroskedasticity test). The findings of these diagnostic tests suggested that the equation has desirable statistical properties. More importantly, the null hypothesis was not rejected in the normality test, which indicated that the residuals that were estimated were normally distributed and the regular statistical inferences (i.e. t-statistic, F-statistic, and R squares) were valid. The findings of the CUSUM (cumulative sum) and CUSUMQ cumulative sum of squares plots showed that the regression coefficients were generally stable across the period of the sample, as well as providing further proof on the robustness of the present analysis. In the long-run, the results indicated that openness, the exchange rate, labour cost and inflation exerted a statistically significant negative effect on the flow of FDI into Malaysia. In contrast, and at the same time horizon, the real interest rate and GDP growth exerted a statistically significant positive impact on the flow of FDI into Malaysia.

Table 5

The long-run analysis, ARDL(3,3,3,4,1,4,4)

\begin{tabular}{|l|l|}
\hline Variables & Coefficients \\
\hline OP & $-0.04^{* * *}$ \\
& {$[0.016]$} \\
\hline EX & $-0.05^{*}$ \\
& {$[0.082]$} \\
\hline RAT & $0.23^{* *}$ \\
& {$[0.022]$} \\
\hline LP & $-0.22^{*}$ \\
& {$[0.09]$} \\
\hline INF & $-0.38^{* *}$ \\
& {$[0.034]$} \\
\hline GDP & $0.14^{* *}$ \\
& {$[0.041]$} \\
\hline C & $15.75^{* *}$ \\
& {$[0.035]$} \\
\hline
\end{tabular}




\begin{tabular}{|c|c|}
\hline \multicolumn{2}{|l|}{ Diagnostic Tests } \\
\hline Serial Correlation & $\begin{array}{l}2.55 \\
{[0.14]}\end{array}$ \\
\hline Functional Form & $\begin{array}{l}3.09 \\
{[0.11]}\end{array}$ \\
\hline Normality & $\begin{array}{l}0.33 \\
{[0.86]}\end{array}$ \\
\hline Heteroscedasticity & $\begin{array}{l}1.84 \\
{[0.18]}\end{array}$ \\
\hline \multicolumn{2}{|c|}{$\begin{array}{l}\text { Note: } \\
* \text { Serial correlation is F- statistics of Breusch-Godfrey serial correlation LM test. B: Functional form is F- statistics of } \\
\text { Ramsey's RESET test using the square of the fitted values. Normality is LM - statistics of skewness and kurtosis of } \\
\text { residuals for normality test. Heteroskedasticity is F- statistics of white Heteroskedasticity test. CUSUM; Cumulative } \\
\text { Sum of Recursive Residuals is the stability test of the long-run coefficients together with the short-run dynamics } \\
\text { based on Pesaran and Pesaran (1997).CUSUMSQ; Cumulative Sum of Squares of Recursive Residuals is the stability } \\
\text { test of the long-run coefficients together with the short-run dynamics based on Pesaran and Pesaran (1997). } \\
* \text { The absolute value for t-statistic in [] \& prob for F-statistic in }() \text {. } \\
*(*),(* *) \text { and }(* * *) \text { denotes significant at } 1 \%, 5 \% \text { and } 10 \% \text { level respectively. }\end{array}$} \\
\hline
\end{tabular}

With regard to the openness variable (OP), the findings of this study suggest that the more open (i.e. low trade cost) a country is to the world, the lower will be the flow of FDI into the country. Malaysia is, in fact, an open economy with an external sector representing more than $200 \%$ of its GDP (gross domestic product). Compared to its neighboring countries, the data on the Economic Globalization Index (Dreher, Noel, and Pim, 2012) show that Malaysia registered a relatively higher score of 78.23 compared with 55.20, 56.12, 63.64 and 47.02 for Indonesia, the Philippines, Thailand and Vietnam, respectively. As previously mentioned, there is a positive relationship between openness and the flow of the horizontal form of FDI, but a negative relationship with the vertical form of FDI. Because of the relatively low cost of trade in Malaysia (high openness), MNCs prefer to export directly to Malaysia instead of investing inside the country. Therefore, the horizontal form of FDI will decrease as the cost of trade decreases (i.e. the country becomes more open).

However, what about the vertical type of FDI? Theoretically, as previously mentioned, the vertical form of FDI is expected to increase with a decrease in the cost of a trade. In fact, the net effect of a reduction in the cost of trade on FDI depends on the cost of labour in the host country compared to the home country. It should be recalled that, when the cost of trade falls, the decrease in the horizontal form of FDI will be dominant over the increase in the vertical form of FDI in the presence of a small difference in labour cost between the home and the host countries; and vice versa, when the difference in labour cost is large. It is well known that since the 1980s Malaysia has suffered from the problem of labour shortages, as reflected by the country's reliance on foreign labour. The country has become a source of income for labour from neighboring countries. The shortage in the labour force implies that the labour cost in Malaysia is relatively high compared to neighboring countries. Since our findings show a negative impact of openness, it is implied that the decrease in the horizontal form of FDI dominates over the increase in the vertical form of FDI. This may indicate, even partly, that the difference in the labour cost between Malaysia and its trading partners is small.

The results also showed that over the long-run, an appreciation of the local currency would have a statistically negative effect on the flow of FDI. As previously mentioned, the sign of the predicted association between FDI and the exchange rate has varied across theoretical models and some models have predicted an ambiguous outcome. This is basically due to the fact that the association between FDI and the exchange rate is dependent on factors such as the configuration of revenues and costs, the type of FDI, or source of exchange rate shock. While the appreciation of the local currency may decrease the flow 
of vertically motivated FDI, it may also increase or decrease the flow of horizontally motivated FDI. Our result shows that, regardless of the type of FDI, the appreciation of the local currency will have a negative impact upon the FDI flow. This may be because a currency appreciation will reduce the revenue of MNCs since it will cause locally produced items to become more expensive abroad. For Malaysia, data on the real effective exchange rate index for the period from 1970 to 2014 shows that the mean of the index depreciated by approximately 100\% (from 215 points in 1970 to 98 points in 2014). Since the findings show a negative relationship between the flow of FDI and the effective exchange rate, the government should continue its efforts in depreciating the local currency since this will reflect in an increase in the flow of both types of FDI. A depreciation in the exchange rate of the host country's currency will have a positive influence on the inflows of horizontal FDI due to the reduced cost of capital. Also, such depreciation will have a positive influence on the flow of vertical FDI because locally produced items will become cheaper abroad. Thus, this will help, to some extent, in attaining the objectives of the ETP

Over the long-run, higher interest rates are associated with significant increases in the level of FDI that flows into a country. This finding parallels the prediction of Jeon and Rhee (2008), that a higher rate of interest in the host country results in foreign investments being more attractive as they lead to more profitable investments. As stated earlier, generally, FDI is financed in the home country. Thus, if the cost of borrowing in the host country is higher than that of the home country, the firm in the home country is likely to have cost advantage over the host country's competitors and is in a stronger position to enter the host country's market through FDI. If the foreign investors obtain their financing facilities in the host country, the result is expected to be negative. Compared to selected neighboring countries, during the period 1990-2014, Malaysia registered an average real interest rate of $3.80 \%$, while during a similar period, for Thailand it was about 5.63\%, Singapore $4.38 \%$, Indonesia $5.72 \%$ and Korea $3.90 \%$. Clearly, Malaysia is at a disadvantage since it has a relatively lower interest rate compared to its neighboring countries. Thus, Malaysia should increase its real interest rate in order to attract foreign investors that are looking for profitable investments

Over the long-run, an increase in the rate of inflation is likely to reflect in a notable adjustment in the amount of the FDI that flows into Malaysia. The Inflation rate confers economic stability, the existence of internal economic tension and the ability of the government to balance the national budget. A high inflation rate reduces the real value of earnings in the local currency for inward investing firms. Data on the inflation rate in Malaysia suggests that the country enjoys a relatively low inflation rate compared to neighboring countries. For instance, during the period 1990-2014 Malaysia recorded an average 2.81\% inflation rate compared to $3.60 \%$ for Thailand, $6.30 \%$ for the Philippines and $10.16 \%$ for Indonesia. Consequently, policymakers should aim at maintaining the current low inflation rate since this will lead to improved inflows of FDI into the economy.

Furthermore, in the long-run, the greater a country's market size is, in terms of GDP, the higher the inbound FDI that will flow into that country. These findings support Dunning's (1993) eclectic paradigm, which asserted that one of the principal motives for firms to invest abroad was to get better access to the host country's market and the markets of neighboring countries. Although over the period of study Malaysia recorded an average 5.89 annual growth rate in GDP, this rate was relatively low when compared to neighboring countries such as China and Singapore which over the same period registered average annual growth rates of $9.92 \%$ and $6.40 \%$ respectively. The government should make extra efforts to promote Malaysia's market size in order to better compete with these countries to attract more FDI. 
Table 6

The short-run analysis, ARDL(3,3,3,4,1,4,4)

\begin{tabular}{|c|c|c|c|}
\hline Variables & Coefficients & Variables & Coefficients \\
\hline$\Delta$ FDI $_{-1}$ & $\begin{array}{c}0.01 \\
{[0.95]}\end{array}$ & $\Delta \mathrm{LP}$ & $\begin{array}{c}-0.88^{*} \\
{[0.08]}\end{array}$ \\
\hline$\Delta$ FDI $_{-2}$ & $\begin{array}{l}-0.22 \\
{[0.30]}\end{array}$ & $\Delta \mathrm{INF}$ & $\begin{array}{l}-0.09 \\
{[0.18]}\end{array}$ \\
\hline$\Delta \mathrm{OP}$ & $\begin{array}{c}-0.2^{* *} \\
{[0.036]}\end{array}$ & $\Delta \mathrm{INF}_{-1}$ & $\begin{array}{c}0.20^{* *} \\
{[0.06]}\end{array}$ \\
\hline$\Delta \mathrm{OP}_{-1}$ & $\begin{array}{c}0.01 \\
{[0.36]}\end{array}$ & $\Delta \mathrm{INF}_{-2}$ & $\begin{array}{c}0.10^{*} \\
{[0.092]}\end{array}$ \\
\hline$\Delta \mathrm{OP}_{-2}$ & $\begin{array}{l}0.01 * * \\
{[0.069]}\end{array}$ & $\Delta \mathrm{INF}_{-3}$ & $\begin{array}{c}0.06 \\
{[0.18]}\end{array}$ \\
\hline$\Delta \mathrm{EX}$ & $\begin{array}{l}0.05^{* *} \\
{[0.023]}\end{array}$ & $\Delta \mathrm{GDP}$ & $\begin{array}{c}-0.07 * * \\
{[0.06]}\end{array}$ \\
\hline$\Delta \mathrm{EX}_{-1}$ & $\begin{array}{c}0.07 * * * \\
{[0.011]}\end{array}$ & $\Delta \mathrm{GDP}_{-1}$ & $\begin{array}{c}-0.25^{* * *} \\
{[0.003]}\end{array}$ \\
\hline$\Delta \mathrm{EX}_{-2}$ & $\begin{array}{c}0.03 \\
{[0.11]}\end{array}$ & $\Delta \mathrm{GDP}_{-2}$ & $\begin{array}{c}-0.19^{* * *} \\
{[0.002]}\end{array}$ \\
\hline$\Delta \mathrm{RAT}$ & $\begin{array}{l}-0.07 \\
{[0.10]}\end{array}$ & $\Delta \mathrm{GDP}_{-3}$ & $\begin{array}{c}-0.11^{* * *} \\
{[0.006]}\end{array}$ \\
\hline$\Delta$ RAT $_{-1}$ & $\begin{array}{c}-0.22^{* * *} \\
{[0.016]}\end{array}$ & $\Delta \mathrm{C}$ & $\begin{array}{l}14.4^{* * *} \\
{[0.012]}\end{array}$ \\
\hline$\Delta \mathrm{RAT}_{-2}$ & $\begin{array}{c}-0.17 * * * \\
{[0.019]}\end{array}$ & $\mathrm{ECT}_{-1}$ & $\begin{array}{c}-0.91^{* * *} \\
{[0.000]}\end{array}$ \\
\hline$\Delta \mathrm{RAT}_{-3}$ & $\begin{array}{c}-0.07^{*} \\
{[0.08]}\end{array}$ & & \\
\hline \multicolumn{4}{|l|}{ Goodness of Fit } \\
\hline $\mathrm{R}^{2}$ & 0.88 & & \\
\hline $\mathrm{R}^{-2}$ & 0.54 & & \\
\hline F-statistic & $\begin{array}{l}3.25^{* * *} \\
{[0.000]}\end{array}$ & & \\
\hline
\end{tabular}

Table 6 presents the short-run findings. The goodness of fit results shows that, in both of the models, the selected explanatory variables explain on average $75 \%$ of the variation in the FDI flows in Malaysia. Besides, as indicated by the F-statistic, each of the variables plays an important role in explaining the FDI flows. The most noteworthy result relates to the coefficient of the ECT-1 which appears negative, less than one as well as statistically significantly higher in both specifications. The ECT-1 explains the adjustment speed to restore equilibrium following a disturbance in the long-run equilibrium relationship. These results can be interpreted as follows: - Given the deviation of FDI from the long-run equilibrium relationship, all the explanatory variables will interact in a dynamic fashion to restore long-run equilibrium. Most importantly, the significance of the ECT-1 also indicated the presence of a causality relationship among the variables, at least in one direction.

The findings indicated that in the short-run, FDI flows were positively influenced by an appreciation of the local currency. It should be recalled that the short-run analysis described the adjustment period or 
the temporary response of FDI to each of the explanatory variables. Horizontally motivated FDI might flow into the country because of the temporary appreciation of the local currency; which implied that local consumers enjoy higher purchasing power. Besides, the lagged coefficient of the interest rate variable is negative and statistically significant. This result implied that in the short-run, a high-interest rate discourages the flow of FDI. As we previously mentioned, a higher interest rate is likely to decrease the flow of FDI since it constitutes an increase in the cost of conducting business in the host country (cost disadvantages). The lagged coefficient of openness variable appears significant and with a positive sign indicating that in the short-run the more open that a country is, the more FDI that will flow into this country. It is possible to interpret this finding according to the two types of FDI (horizontal and vertical) and the labour cost between the home and the host country. It seems that in the short-run, foreign investors will respond to a country that is more open by increasing vertical FDI and decreasing horizontal FDI; since the difference in the labour cost is likely to be large in the short-run. This is because policies that aim to increase the labour force (decrease the cost of labour) will take time (long-run) and this must be taken into account by foreign investors.

The lagged coefficients of the inflation and GDP variables had unexpected signs. More specifically, in the short-run, our results showed that FDI will respond negatively to an increase in the host country's market size and positively to the inflation rate. However, Masih and Masih (2004) cautioned against placing too much emphasis on such short-run relationships as they are derived from a reduced -form mode and are not based on theory.

\subsection{Variance decomposition analysis}

Variance decomposition (VD) analysis reveals the forecast error variance as a percentage for each variable due to its own innovations and shocks to the other system variables. The variance decompositions utilised in this study were estimated by disturbing each underlying variable in the estimated system by one standard deviation. Following this disturbance, the forecast error variance for each variable was decomposed into the proportion attributed to each of the random shocks. Table 7 presents the variance decomposition with a 10-year horizon for the model under study. The table shows that, on average, approximately $48 \%$ of the variations in the forecast errors for FDI over the 10-year horizon can be explained by the innovations of the FDI. A shock in the exchange rate, interest rate, GDP, labour cost, inflation and openness, explains, on average, approximately $16 \%, 9 \%, 8 \%, 7 \% 6 \%$ and $5 \%$ of the variance in the flows of FDI, respectively. Clearly, among the explanatory variables, the exchange rate tends to be the more significant variable in the flow of FDI compared to the rest of the variables. For robustness, we re-ordered the variables; however, the results remained the same.

Table 7

Variance decomposition analysis

\begin{tabular}{|c|c|c|c|c|c|c|c|c|}
\hline Period & S.E. & DFDI & DEX & DINF & DLP & DOP & GDP & RAT \\
\hline 1 & 0.668329 & 100.0000 & 0.000000 & 0.000000 & 0.000000 & 0.000000 & 0.000000 & 0.000000 \\
\hline 2 & 0.696586 & 92.30452 & 1.008759 & 2.668331 & 1.158773 & 0.053102 & 1.697961 & 1.108549 \\
\hline 3 & 0.702731 & 90.86300 & 1.737476 & 2.624610 & 1.306902 & 0.414097 & 1.906199 & 1.147717 \\
\hline 4 & 0.746116 & 85.18467 & 4.384762 & 2.372813 & 1.386927 & 2.158210 & 3.441223 & 1.071399 \\
\hline 5 & 0.787545 & 77.82038 & 10.10401 & 2.347945 & 1.244849 & 2.920452 & 4.598031 & 0.964334 \\
\hline 6 & 0.806835 & 74.21014 & 10.33089 & 3.370931 & 2.542624 & 4.207739 & 4.381623 & 0.956050 \\
\hline 7 & 0.828954 & 71.04578 & 9.848736 & 3.253511 & 3.925999 & 4.298670 & 6.157430 & 1.469871 \\
\hline 8 & 0.875988 & 64.07648 & 11.46570 & 3.160376 & 6.326161 & 4.411564 & 5.591912 & 4.967808 \\
\hline 9 & 0.921889 & 57.85466 & 10.61913 & 4.354403 & 8.186736 & 4.950142 & 6.336675 & 7.698257 \\
\hline 10 & 1.012151 & 48.60558 & 16.18462 & 6.548108 & 7.044447 & 4.759200 & 7.656986 & 9.201061 \\
\hline
\end{tabular}




\section{CONCLUSION AND POLICY IMPLICATIONS}

With the current trend in the FDI that inflows to Malaysia, the dreams of the Malaysian people to be among the high-income countries in the coming years will be challenging. This because new information on the distribution of FDI worldwide shows that Malaysia has only been able to attract a small number of foreign investors. This study examined the effect of macroeconomic factors implemented by the host country on inbound FDI (Foreign Direct Investment) under the location-specific advantage. The study employed the ARDL model (Auto-Regressive Distributed Lag model) together with the VAR model (Vector Autoregressive model) on annual data covering the period 1970-2014. The study found that over time, the exchange rate, trade openness, inflation and the labour cost had a negative and significant effect on inbound FDI. However, over the longer-term, the real interest rate and GDP growth produced substantial positive results. According to these findings, the decrease shown in the flow of FDI into the country was partly due to inappropriate international trade policies (openness) and the high cost of labour. To create an attractive environment for FDI, the government must give close attention to its macroeconomic policies specifically those policies related to openness, migration policies (labour cost) and monetary policies.

Although this study covered a critical aspect of FDI, some limitations of the study still exist and are important areas for future research. Future studies may contribute to this issue by, for instance, introducing alternative macroeconomic variables, different methodology and techniques.

\section{REFERENCES}

Aliber, R.Z. (1993). The Multinational Paradigm, Cambridge (Massachusetts). MIT Press.

Banerjee, A. J., Dolado, J., \& Mestre, R. (1998). Error-Correction Mechanism Tests for Cointegration in SingleEquation Framework. Journal of Time Series Analysis, 19, 267-283.

Billington, N. (1999). The location of foreign direct investment: an empirical analysis. Applied Economics, 31, 65-75.

Boateng A., Hua X., Nisar, S., \& Wu, J. (2015). Examining the determinants of inward FDI: Evidence from Norway. Economic Modelling, 47, 118-127.

Boateng, A., Naraidoo, R., \& Uddin, M. (2011). An analysis of the inward cross-border mergers and acquisitions in the UK: a macroeconomic perspective. International Journal of Finance, Management and Account, 22, 2, 91-112.

Brown, R.L. Durbin, J., \& Evans, J.M. (1975). Techniques for testing the constancy of regression relationships over Time. Journal of the Royal Statistical Society, Series 37,149-92.

Buckley, P.J., Clegg, L.J., Cross, A.R., Xin, L., Voss, H., \& Ping, Z. (2007). The determinants of Chinese outward foreign direct investment. Journal of international Business Studies, 38, 499-518.

Busse, M., \& Hefeker, C. (2007). Political risk, institutions and foreign direct investment. European Journal of Political Economy, 23, 397-415.

Carr, L. Markusen, R., \& Maskus, E. (2001).. Estimating the Knowledge-Capital Model of the Multinational Enterprise. American Economic Review, 91, 20, 693-708.

Cavallari, L., \& D'Addona, S. (2013). Business cycle determinants of US foreign direct investments. Applied Economics Letters, 20,10, 966-970.

Choong, C.K., Yusop, Z., \& Soo, S.C. (2005). Foreign direct investment and economic growth in Malaysia: the role of domestic financial sector. Singapore Economic Review, 50, 245-268.

Coskun, R. (2001). Determinants of direct foreign investment in Turkey. European Business Review, 1, 4, 221-226.

Culem, C. (1988). Direct investment among industrialized countries. European Economic Review, 32, 885-904.

Dickey, D.A., \& Fuller, W.A. (1981). Likelihood ratio statistics for autoregressive time series with a unit root. Econometrica, 49, 1057-1072.

Dreher, A., Noel, G., \& Pim, M. (2012). Measuring globalisation - gauging its consequences. New York: Springer.

Dunning, J. (1998). Toward an eclectic theory of international production: Some empirical tests. Journal of International Business Studies, 11,9-31. 
Dunning, J. (2009). Location and the multinational enterprise: A neglected Factor?. Journal of International Business Studies, 40, 5-19.

Dunning, J. (1980). Location and the multinational enterprise: A neglected Factor?, Journal of International Business Studies, 40, 5-19.

Dunning, J. (1988). The Eclectic Paradigm of International Production: A Restatement and Some Possible Extensions. Journal of International Business Studies, 19, 1, 1-31.

Dunning, J. (1993). Multinational Enterprises and the Global Economy, Addison-Wesley Publishers, London.

Egger P, \& Merlo, V. (2007). The Impact of Bilateral Investment Treaties on FDI Dynamics. The World Economy, 30 , 1536-1549.

Faeth, I. (2009). Determinants of foreign direct investment - a tale of nine theoretical models. Journal of Economic Surveys, 23, 1, 165-196.

Fedderke, J.W., \& Romm, A.T. (2006). Growth impact and determinants of foreign direct investment into South Africa, 1956-2003. Economic Modeling, 23, 738-760.

Helpman, E., \& Krugman, P. (1985). Market Structure and Foreign Trade. Cambridge: MIT Press.

Helpman, E. (1984). A simple theory of trade with multinational corporations. Journal of Political Economy, 92, 451471.

Hong, K.K., \& Kim, Y. G.(2002). The critical success factors for ERP implementation: an organizational fit perspective. Information Management, 40, 25-40.

Hossain, S., \& Mitra, R. (2013). A Dynamic Panel Analysis of the Determinants of FDI in Africa. Economics Bulletin, 33, 2, 1606-1614.

Jang, Y. (2011).The Impact of Bilateral Free Trade Agreements on Bilateral Foreign Direct Investment among Developed Countries. World Economy, 34, 9, 1628-1651.

Jeon, B. N., \& Rhee, S. S. (2008). The Determinants of Korea "es Foreign Direct Investment from the United States, 1980-2001: An Empirical Investigation of Firm Level Data. Contemporary Economic Policy, 26, 1,118-131.

Kwiatkowski, D., Phillips, C.B., Schmidt, P., \& Shin, Y. (1992). Testing the Null Hypothesis of Stationarity against the Alternative of a Unit Root. Journal of Econometrics, 54, 159-178.

Lautier, M., \& Moreaub, F. (2012). Domestic investment and FDI in developing countries: The missing link. Journal of Economic Development, 37, 3, 1-23.

Lesher, M., \& Miroudot, S. (2006).Analysis of the economic impact of investment provisions in regional trade agreements, OECD Trade Policy Working paper \#36.

Levy-Yeyati, E., Ernesto, S., \& Christian, D. (2003). Regional Integration and the Location of FDI. IADB Research Department Working Paper 492, InterAmerican Development Bank, Washington, D.C.

Marashdeh, H. (2005). Stock market integration in the MENA region: An application of the ARDL bounds testing approach. University of Wollongong.

Markusen, J. (1984). Multinationals, Multi-plant Economies, and the Gains from Trade. Journal of International Economics, 16, 205-226.

Markusen, J., \& Venables, A. (1998). Multinational Firms and the New Trade Theory. Journal of International Economics, 46, 183-204.

Moosa, I. A., \& Cardak, B.A. (2006). The determinants of foreign direct investment: an extreme bounds analysis. Journal of Multinational Finance and Management, 16, 199-211.

Mosayeb, P., \& Mohammad, R. (2009). Sources of inflation in Iran: An application of the ARDL approach. International journal of Applied Econometrics and Quantitative Study, 9(1).

Noorbakhsh, F., Paloni, A., \& Youssef, A. (2001). Human Capital and FDI Flows to Developing Countries: New Empirical Evidence. World Development, 29, 1593-1610.

Ozturk, I., \& Acaravci, A. (2011). Electricity consumption and real GDP causality nexus: Evidence from ARDL bounds testing approach for 11 MENA countries. Applied Energy, 88,2885-2892.

Pesaran, H.M., \& Pesaran, B. (1997). Working with Microfit 4.0. Oxford University Press: Oxford.

Pesaran, M.H., Shin, Y., \& Smith, R.J. (2001). Bounds testing approaches to the analysis of level relationships. Journal of Applied Econometrics 16, 289-326. 
Phillips, S., \& Ahmadi-Esfahani, F. Z. (2008). Exchange Rates and Foreign Direct Investment: Theoretical Models and Empirical Evidence. The Australian Journal of Agricultural and Resource Economics, 52, 505-525.

Polyxeni, K., \& Theodore, M. (2019). An empirical investigation of FDI inflows in developing economies: Terrorism as a determinant factor. The Journal of Economic Asymmetries, 20,e00125.

Saini N., \& Singhania, M.(2018). Determinants of FDI in developed and developing countries: a quantitative analysis using GMM. Journal of Economics Studies, 45(2): 348-382, https://doi.org/10.1108/JES-07-2016-0138.

Uddin, M., \& Boateng, A. (2011). Explaining the trends in the UK cross-border mergers and acquisitions: an analysis of macro-economic factors. International Business Review, 20, 547-556.

Uddina, M., Chowdhury, A., Zafarc, S., Shafiqueb, S., \& Liu, J.(2019). Institutional determinants of inward FDI: Evidence from Pakistan. International Business Review, 28, 344-358.

UNCTAD. (1994). Foreign Direct Investment and the Challenge of Development. United Nation Conference on Trade and Development (UNCTAD), New York and Geneva.

UNCTAD. (1999). Foreign Direct Investment and the Challenge of Development. United Nation Conference on Trade and Development (UNCTAD), New York and Geneva.

Vasconcellos, G. M., \& Kish, R.J. (1998). Cross-border mergers and acquisitions: the European- US experience. Journal of Multinational Finance and Management, 8, 4, 431-450.

Wadhwa, K., \& Reddy, S. (2011). Foreign Direct Investment into Developing Asian Countries: The Role of Market Seeking, Resource Seeking and Efficiency Seeking Factors. International Journal of Business Management,6, 11, 219-226.

Xaypanya, P., Rangkakulnuwat, P., \& Paweenawat, S. (2015). The determinants of foreign direct investment in ASEAN: The first differencing panel data analysis. International Journal of Social Economics 42, 3, 239-250.

Xuan Vinh, V. (2018). Determinants of Capital Flows to Emerging Economies - Evidence from Vietnam.Finance Research Letters, doi: 10.1016/j.frl.2018.02.031.

Yang, J.Y., Groenewold, N., \& Tcha, M. (2000). The Determinants of in Australia. The Economic Record, 76, 45-54. 